\title{
Conversando com a comida: MasterChef e o solilóquio como acesso privilegiado à autenticidade ${ }^{1}$
}

\section{Talking to the food: MasterChef and the soliloquy as a privileged access to authenticity}

\section{Carlos Eduardo Marquioni}

Professor do Programa de Pós-Graduação em Comunicação e Linguagens da Universidade Tuiuti do Paraná (UTP). Mestre e Doutor em Comunicação e Linguagens pela UTP. Membro dos grupos de pesquisa: Interações comunicacionais, imagens e culturas digitais (INCOM/PPGCOM UTP) e Estudos Culturais (GECU/UNESP-Franca).

<cemarquioni@uol.com.br>

\section{Fernando Andacht}

Professor titular no Departamento de Teoria e Metodologia da Faculdade de Informação e Comunicação da Universidade da República - Uruguai. É professor compartilhado do PPGCOM/UTP.

$<$ fandacht@gmail.com>

\section{RESUMO}

O artigo propõe uma análise e uma contextualização histórica dos componentes da franquia televisual de competição gastronômica MasterChef enquanto um híbrido entre reality show e talent show. Complementarmente à revelação da competência culinária dos participantes (talent), o público tem acesso ao que consideraria como as emoções autênticas dos aspirantes a chef (reality), à sua intimidade, através do uso recorrente, na economia narrativa do programa, de uma forma de fala pouco natural no cotidiano: o solilóquio. Realizando uma recuperação histórica dessa classe de monólogo na literatura e no teatro, é apresentada uma tentativa de compreensão de como se dá o fenômeno que os autores defendem como o efeito de autenticidade em MasterChef. São analisadas cinco variantes de solilóquio na franquia, a partir de episódios das edições brasileira, argentina e estadunidense do programa.

\begin{abstract}
The article posits an analysis and a historical contextualization of the television franchise of gastronomic competition MasterChef construed as a hybrid of reality show and talent show. Together with the revelation of the culinary competence of the participants (talent), the audience has access to what they are expected to consider to be the authentic emotions of the aspiring chefs (reality), to their intimacy, through the recurrent use in the narrative economy of the program of a way of talking that is unnatural in everyday life, namely, the soliloquy. By revisiting the history of this kind of monologue in literature and drama, we present an attempt to understand what the authors argue is the phenomenon of the authenticity effect in MasterChef. We analyze five variants of the soliloquy in the franchise; they are drawn from episodes of the Brazilian, Argentinian and American editions of the TV show.
\end{abstract}

Keywords: Reality show. Soliloquy. Indexicalsigns.

1 Uma versão do artigo foi apresentada no congresso da Compós/2016 (UFG). 


\section{Introdução}

Este artigo propõe uma análise e reflexões históricas relacionadas a uma investigação em curso sobre o sucesso em escala mundial alcançado pela franquia televisual de competição gastronômica MasterChef (daqui por diante $M C$ ): este programa de TV é abordado aqui para além de uma produção que visa selecionar o melhor cozinheiro amador de um grupo (alçando-o ao status de chef de cozinha), ou mesmo como um programa através do qual a audiência aprenderia receitas e montagens sofisticadas de pratos. $M C$ é avaliado enquanto oferta televisual que promete tacitamente um acesso ao que seriam consideradas por seu público como as emoções autênticas dos participantes, sua intimidade: tal acesso seria materializado principalmente através das ocorrências de solilóquio no programa.

Solilóquio pode ser definido "Inicialmente [...] como alguém falando em voz alta consigo mesmo. [...] Trata-se de um elemento de composição intencional do drama: uma modalidade de fala dramática" (Williams, 2008, p. 139)². O uso deste recurso dramático pode ser observado nos programas do gênero reality show, tanto na "melocrônica juvenil da ordem interacional" (Andacht, 2003, p. 68) Big Brother quanto no formato MC. O termo 'solilóquio' é apresentado por Williams ainda como a forma verbal paralela latina do monólogo ${ }^{3}$ (uma vez que para este trabalho o aspecto da noção técnica teatral não é central, os dois conceitos são abordados como sinônimos). Ocorre que a "telerrealidade capitaliza uma variedade de situações da fala no mesmo programa, mas é o monólogo que é utilizado como um signo verdadeiro de acesso ao autêntico" (Aslama; Pantti, 2006, p. 167). De fato, viveríamos uma "cultura confessional contemporânea" (Aslama; Pantti, 2006, p. 168) associada à exibição pública de sentimentos que eram tradicionalmente privados (Aslama; Pantti, 2006, p. 168). Nessa "cultura confessional" (ou terapêutica), em que o "Interesse nas emoções das outras pessoas parece constituir uma parte da cultura contemporânea" (Aslama; Pantti, 2006, p. 167), o solilóquio teria um papel central. Devemos observar um aspecto relevante em relação aos solilóquios em $M C$, que constitui

2 A seção seguinte apresenta o solilóquio de modo detalhado (inclusive realizando breve contextualização histórica do uso do recurso na literatura e no teatro).

3 Williams informa que segundo o "ModernEnglishUsage, de Fowler (1926), em 'termos técnicos': Monólogo: (Lit.); 'fala solitária'. O monólogo e o solilóquio são termos paralelos de origem grega e latina; mas o uso tende a restringir solilóquio à fala consigo mesmo e ao pensamento em voz alta, sem a consciência de um público, de ser ouvido por alguém ou não; já o monólogo, embora inversamente não seja restrito ao discurso de uma única pessoa que esteja sendo ouvida, é mais frequentemente entendido nesse sentido, e é especialmente usado com relação a um falante que monopoliza a conversa ou a uma recitação ou encenação dramática em que há apenas um ator" (2013, p. 53). 
uma característica que os tornaria algo distintivo na franquia e, em certa medida, diferentes daqueles solilóquios praticados em outros programas de telerrealidade.

Entende-se que $M C$ constitui um híbrido entre reality show e talent show: complementarmente à expectativa da audiência pela contemplação dos sofisticados pratos elaborados pelos competidores, haveria também em um programa que, a priori, teria pouco ou nada a ver com as emoções ${ }^{4}$, a promessa (tácita) de acesso à intimidade dos indivíduos, ao "si mesmo real" deles (Aslama; Pantti, 2006, p. 181). Assim, o gênero da reality television teria a "atração chave de revelação de emoções 'verdadeiras"' (Aslama; Pantti, 2006, p. 168), enquanto o aspecto talento formato MC associa-se ao fornecimento de competências específicas e verificáveis dos participantes em relação ao ato de cozinhar5; o aspecto do produto que obrigatoriamente deve ser produzido, entregue e julgado por especialistas para que os competidores continuem no programa habilitaria acesso a essa segunda sorte de competências.

E vale destacar uma breve nota sobre o caráter indicial - conforme a teoria semiótica peirceana - do monólogo: ocorre que nele misturam-se elementos simbólicos (a fala) inseparáveis de signos do corpo, quais sejam, as expressões emocionais enquanto sintomas. Para compreender a importância semiótica desse segundo elemento, pode ser considerado que:

Cada vez que chegamos a conhecer um fato, isso é pela sua resistência a nós. [...] Podemos, porém, conhecer sobre um fato de modo indireto. Ou o fato foi experimentado diretamente por alguma outra pessoa cujo testemunho chega a nós, ou o conhecemos por algum efeito físico dele. Assim nós observamos que os efeitos físicos de um fato podem ocupar o lugar da experiência do fato por uma testemunha (CP 1.4316).

4 Este componente televisual baseia-se essencialmente no caráter de entrega de um produto que requer competência para elaboração associado: "Ou bem você deliver [um prato], ou bem você está fora [é eliminado da competição]. [...] Então, tem um produto [a entregar]: eles têm uma produção efetiva, real. Eles precisam de um prato [...] para eles continuarem no programa e efetivamente ganharem os prêmios finais" (Padrão, 2014, grifo nosso).

5 Em síntese, o aspecto de talent show é associado à apresentação de habilidades concretas e específicas dos participantes (no caso de $M C$, habilidades gastronômicas).

6 A obra de Peirce é citada do modo habitual: x.xxx, que corresponde ao volume e ao parágrafo da edição dos CollectedPapersof C. S. Peirce. A tradução é nossa. 
Pode-se, assim, afirmar que o espectador ideal de $M C$ não é apenas um aprendiz de cozinha ou um fã de gastronomia (como no caso do programa clássico de culinária), ou um mero torcedor de mais uma competição televisiva mas também (e sobretudo) uma testemunha dos conflitos da alma dos participantes que sonham em ser chefs. O que pode ser considerada a dimensão psicológica de $M C$ seria então conhecida materialmente menos através dos signos simbólicos e muito mais através dos indiciais, os efeitos físicos observados nos monólogos. A noção chave aqui é a de resistência: haveria um processo fisiológico e psíquico que é mais forte que a pessoa, um elemento que produziria uma dificuldade durante sua performance culinária e identitária (a qual explica e gera o efeito de autenticidade para o espectador). Entende-se que seja mais justo falar aqui da procura de 'signos' que são interpretados como autênticos, se pensarmos em termos do processo de autenticação, porque "a autenticidade é algo que alguém efetua [performs]" (Wilce; Fenigsen, 2015, p. 145). Ao menos em algumas das funções do solilóquio (particularmente naquelas de tipo confessional - conforme apresentadas adiante), MC constrói uma encenação dramatúrgica na qual os participantes parecem não resistir a expressar corporalmente o que estão sentindo ou pensando.

$\mathrm{O}$ acesso à intimidade através do solilóquio se daria em $M C$ em múltiplas variantes ${ }^{7}$, que procuram criar um efeito de autenticidade, com destaque para (i) a confissão/revelação emocional, (ii) a confissão vergonhosa ou íntima, (iii) a glosa ou comentário completamente corriqueiro, (iv) a forma híbrida ou impura do solilóquio e o que se considera como (v) a propaganda quase explícita do show: uma apologia pro realidade sua. Para os cinco casos é possível traçar uma relação com o monólogo indireto reflexivo, que no teatro costuma ser "mais amplamente generalizado como solilóquio, no qual uma prática auto discursiva é falada na primeira pessoa com o ator sozinho no palco" (Williams, 2013, p. 65). Neste artigo, os cinco casos são analisados considerando programas das edições brasileira, argentina e estadunidense da franquia ${ }^{8}$. Assim, a pesquisa qualitativa de uma explicação para o sucesso da franquia MC em âmbito mundial é conduzida neste artigo procurando responder por que uma forma tão pouco

7 A explicação e exemplos de cada variante são apresentados na segunda seção deste artigo.

8 Todas as referências neste artigo à edição brasileira (apontadas como MC-BR ao longo do texto) foram obtidas no episódio 09 da primeira temporada; as referências à edição estadunidense (apontadas como MC-US) foram obtidas no episódio 06 da terceira temporada; finalmente, as referências à edição argentina (apontadas como MC-AR) foram obtidas no episódio 16 da segunda temporada. Os conteúdos mencionados, assim como as imagens utilizadas, foram obtidos no site youtube.com. Acessos realizados entre os dias 04 dez. 2015 e 27 jan. 2016. 
natural da fala como o solilóquio (algo praticamente ausente da vida cotidiana) poderia explicar boa parte da popularidade de $M C$.

O presente trabalho é dividido em duas seções, além desta Introdução e das Considerações finais. Em Solilóquio: um complexo recurso dramático para produção de autenticidade é apresentada a noção de solilóquio, para contextualizar historicamente (ainda que brevemente) sua forma de uso na literatura e no teatro, até alcançar a maneira como o dispositivo dramatúrgico vem sendo utilizado em programas de telerrealidade; a abordagem procura auxiliar a compreender como ocorre a referida produção do efeito de autenticidade. Na seção Solilóquio em MasterChef: acesso à intimidade a partir da cozinha é realizada análise do corpus de pesquisa (é apresentado o funcionamento das cinco variantes de solilóquio listadas anteriormente na economia narrativa de M).

Solilóquio: um complexo recurso dramático para produção de autenticidade

Para compreender a geração do efeito de autenticidade a partir do solilóquio, uma abordagem interessante envolve resgatar as formas como esta modalidade de monólogo tem sido utilizada como recurso dramático na literatura e no teatro.

Neste sentido, enquanto a definição de diálogo tem se mantido relativamente estável ${ }^{9}$, para o monólogo a situação é mais complexa. No caso do solilóquio, o "termo soliloquium, do latim tardio, é tirado comumente do Libersoliloquiorum, de Agostinho, cujos subtítulos são: 'Soliloquia animae ad Deum' e 'Meditationes, soliloquia etmanuali' [;] [...] solilóquio, nesse caso, não é uma questão de representação de uma fala por uma única pessoa" (Williams, 2013, p. 53-54, grifos no original). De fato, em relação aos escritos de Santo Agostinho, o solilóquio "aparece frequentemente em uma forma dialogada, por exemplo, entre a alma e Deus ou entre as diversas faculdades mentais. [...] [N]o início do século XVII, [é abordado também] como 'conversa privada' (Williams, 2013, p. 54).

Essa espécie de diálogo interior (quer a conversa com Deus na alma da pessoa, ou das faculdades mentais de uma mesma e única pessoa) é um antecedente textual e cultural do aspecto confessional do solilóquio como ele é abordado nos reality shows. Ora, é possível considerar que falar com Deus

9 A definição de diálogo tem associado o "sentido geral [...] de uma conversa entre duas ou mais pessoas" (Williams, 2013, p. 39) 
(na tradição judaico-cristã) ou pensar sobre si próprio constituem o oposto de falar com outro (de dialogar). Interessa a este artigo também essa dimensão espiritual associada ao termo, pois ela auxilia a conduzir à crença pela audiência na expressão autêntica da identidade ou si mesmo da pessoa que participa do reality show: afinal de contas, você pode tentar convencer o outro, mas há que se supor que ao falar consigo mesmo há um ato de sinceridade a priori, da verdade definitiva da pessoa, uma vez que ela não estaria sujeita ao julgamento dos outros porque toda a fala acontece em seu interior ${ }^{10}$.

Em relação ao teatro, um caso interessante do solilóquio pode ser observado enquanto elemento da poética teatral isabelina na Inglaterra do século XVII, associado a mudanças no âmbito macrossocial: particularmente o surgimento da burguesia e da noção de indivíduo na Europa. O solilóquio pode, nesse contexto, ser compreendido enquanto estratégia dramática que materializou "novas e sutis modalidades e relações [que] foram [...] evoluções na prática social, e estão fundamentalmente vinculadas à descoberta, na forma dramática, de relações sociais novas e modificadas, percepção do eu e dos outros, alternativas complexas de pensamento privado e público" (Williams, 2008, p. 141, grifo no original). Há que se observar, contudo, que neste âmbito não haveria uma relação causal direta entre mudanças sociais e as convenções do teatro da época, mas uma tensão dialética estabelecida entre as mudanças no teatro e o contexto social associado:

a inovação formal é um elemento genuíno e integrante das próprias mudanças: uma sistematização, por meio da descoberta técnica, de mudanças na consciência que são, elas mesmas, formas de consciência da mudança. Assim, o estudo do solilóquio no teatro renascentista inglês é [...] um tipo novo e tecnicamente rigoroso de análise social (Williams, 2008, p.141-142).

Especialmente a partir do século XVIII, estabelece-se no teatro o sentido de solilóquio enquanto o indivíduo falando consigo, baseado na convenção

10 É importante observar que no caso de programas do gênero reality show há um entrevistador ou interlocutor da produção (tipicamente invisível ao público espectador, mas imaginável), responsável por elaborar perguntas às quais o participante responde, gerando um efeito de monólogo (de reflexão consigo mesmo). Este entrevistador invisível é abordado adiante neste artigo, particularmente quando tratada a variante de solilóquio apresentada como caracterizando (iv) a forma híbrida ou impura do solilóquio (situação em que a presença do interlocutor parece ser mais evidente). 
de que quanto um ator fala durante a encenação, se "não há outro ator no palco com quem esse ator converse, então ele deve estar conversando consigo mesmo" (Williams, 2013, p. 41, grifo no original). A convenção era associada a uma outra, de que no teatro moderno haveria "um público que apenas assiste e escuta, e de atores que falam e se comportam como se ninguém os estivesse vendo e escutando (às escondidas)" (Williams, 2013, p. 40). O fato é que "tradicionalmente, tanto no drama quanto na prosa, a fala de uma pessoa sozinha tem sido utilizada para revelar [ao público] a vida interior, pensamentos secretos e sentimentos dos personagens" (Aslama; Pantti, 2006, p. 175). O cenário apresentado até o momento (desde os textos de Santo Agostinho até os comentários do teatro inglês no século XVII) permite considerar a existência em $M C$ de uma ressignificação midiática envolvendo uma forma de comunicação artística bastante antiga, com outra que chega à audiência de TV no fim do século XX através dos programas do gênero reality show. Também ajuda a compreender a relevância atual do monólogo neste gênero televisivo uma tendência histórica que o filósofo canadense Charles Taylor (2007) chama de "cultura da autenticidade", e se define

por uma compreensão da vida que emerge junto com a expressividade do Romantismo de fins do século 18 , de que cada um de nós possui seu próprio modo de realizar sua humanidade, e que é importante achar e por em prática o próprio, contra se render ao conformismo de um modelo que nos foi imposto de fora (Taylor, 20078, p. 475).

Não é uma ironia histórica menor o fato de que um gênero tão artificial e comercial como o reality show em seus inúmeros formatos seja considerado como um dos modos "próprios de realizar a humanidade" de cada pessoa, o objetivo procurado pela expressividade no Romantismo e teorizado por JeanJacques Rousseau.

Mas outra característica merece ainda ser observada, associada ao fato de que o caso de um indivíduo falar diretamente ao público seria "congruente com uma distribuição estável de autoridade e de ocasião para falar: uma distribuição sistemática de papéis de quem fala e de quem escuta" (Williams, 2008, p. 144). Essa autoridade atribuída a quem fala (associada à distribuição clara de papéis) parece atestar, no reality show, a "transformação de uma pessoa ordinária em uma estrela" (Aslama; Pantti, 2006, p. 178). Uma vez que toda a atenção e a 
tensão dramática focalizam-se no protagonista do monólogo, o personagem do participante de $M C$ cresce, e

o monólogo focaliza a atenção intensamente no falante e no modo em que ela ou ele se expressa a si mesmo. A linguagem, a dinâmica dos elementos narrativos e linguísticos são, como resultado, colocados em primeiro plano [foregrounded]" (Wallace, 2006, p. 06).

Para concluir essa breve contextualização histórica, como já mencionado anteriormente, foi "sobretudo no movimento romântico" que o acesso aos pensamentos passou a abordar principalmente o que se considera como uma "análise 'psicológica' cada vez mais íntima dos personagens" (Williams, 2013, p. 56, grifo nosso). Em relação a esse elemento psicológico, a exibição da intimidade parece constituir justamente o objetivo primário do solilóquio usado no gênero reality show em geral. Quanto ao formato $M C$, entende-se que efetivamente sem uma viagem pela psique dos participantes em uma espécie de "produção de auto-revelação" (Aslama; Pantti, 2006, p. 168), o programa apresentaria tão somente a competência potencial de futuros chefs. Ainda que esta fórmula constituísse uma adaptação do típico programa de culinária, parece pouco provável que ela seria suficiente para que fosse alcançado o sucesso mundial observável com a franquia"1. Mas há que se considerar que o recurso do solilóquio não garante necessariamente o acesso ao autêntico (ao menos, não o tempo todo); em função da supressão da "ilusão dramática" pode haver aspectos cujos efeitos são opostos:

\begin{abstract}
O ato literal de se despir do performer pode ser considerado como um meio de exibir um si mesmo 'verdadeiro' e ao mesmo tempo chocar ou dar vergonha na audiência. Mas as possibilidades de que o falante não seja completamente confiável, ou que possa ser um farsante deliberado, de que como espectadores nós podemos adotar o papel de confessores, ou pior ainda, de voyeurs, fica no ar nos bastidores (Wallace, 2006, p. 6).
\end{abstract}

11 Afinal de contas, há que se considerar que os programas de culinária constituem um caso de programa de TV de nicho, orientado a um público específico. Este, definitivamente, não parece ser o caso em $M C$. 
Em termos semióticos, é possível considerar o efeito dessa fala tão particular que é o monólogo (de natureza literária e teatral em sua origem) como se fosse um interpretante peirceano ${ }^{12}$ - no caso de $M C$, um signo mais desenvolvido daquilo que o espectador assiste, ouve, e sente quando os participantes atuam no programa ${ }^{13}$. A performance física e verbal observada durante o solilóquio torna os participantes uma espécie de apresentadores alternativos de MC. Mas há que se observar que se trata de um formato de apresentação especial (distinto daquele dos apresentadores oficiais da franquia): o aspecto especial deve-se ao fato de que os participantes revelam, durante seus monólogos, o si mesmo, sua própria identidade nos ordálios (uma versão moderna e midiática das terríveis provas jurídicas e teológicas medievais de inocência) que devem ultrapassar para continuarem na narrativa épica de $M C$ e se converter no eventual vencedor final. Assim, durante a narrativa definida para o programa (mantida através de recursos de edição), um olhar ou uma palavra dos chefs/jurados (seja de aprovação ou crítica) via de regra produz um discurso expressivo forte, marcante, e marcado (não corriqueiro): o solilóquio do participante ao qual foi orientado o comentário - quer um elogio, quer uma crítica.

Há que se observar, ainda, que, do ponto de vista da produção, esse solilóquio que, em função de recursos de edição do programa, é apresentado tipicamente imediatamente após o comentário dos chefs/jurados, normalmente é obtido após a confecção dos pratos, quando os participantes gravam depoimentos isoladamente nas dependências do estúdio que compõe a cozinha $\mathrm{MC}^{14}$. Além de ser uma fala, como quando um participante responde a

12 "O signo dirige-se a alguém, isto é, ele cria na mente dessa pessoa um signo equivalente, ou talvez um signo mais desenvolvido. O signo que aquele cria eu chamo de interpretante do primeiro signo" (CP 2.228, grifo nosso).

13 Merece ser citado ainda um outro exemplo de interpretante (diferente do solilóquio) e que faz parte do gênero reality show e do formato MC (particularmente no caso da edição brasileira da franquia). Trata-se de uma espécie de votação que é apresentada na tela durante a veiculação do programa na TV, e que registra opiniões do público (ora sobre quem deveria ser o participante eliminado, ora em relação a qual participante deveria retornar ao programa, ou mesmo questões que envolvem aspectos de harmonização entre pratos e bebidas). Trata-se de um julgamento puramente quantitativo, não verbal, que constitui um tipo de intervenção que remete a uma estratégia típica do reality Big Brother Brasil (a exibição na tela das pulsações dos moradores que foram submetidos ao voto popular em relação à continuidade no programa).

14 Há ainda outra situação de depoimentos dos participantes em MC, realizados enquanto ocorre o preparo dos pratos. Apesar de o formato de edição sugerir se tratar de um monólogo em formato estrito, durante visita de um dos autores do presente trabalho aos estúdios de gravação do programa (quando foi acompanhada a gravação de um programa da franquia brasileira), foi possível observar que efetivamente os depoimentos obtidos durante o preparo dos pratos contam com o apoio de um profissional da equipe de produção, que faz perguntas aos participantes. Tais perguntas não são 
uma pergunta ou a uma crítica de um chef, essa é uma opção verbal artificial, nada semelhante ao que acontece na vida cotidiana: um ato de fala que se pode imaginar acontecendo em silêncio no pensamento da pessoa.

\section{Solilóquio em MasterChef: acesso à intimidade a partir da cozinha}

Realizada a apresentação do solilóquio da seção anterior, nesta parte é descrito o leque de funções e objetivos do solilóquio no mecanismo de $M C$; abordam-se aqui a análise das variantes dessa situação de fala e sua contribuição na economia narrativa do programa televisivo, considerando os cinco casos listados na Introdução. Espera-se, assim, apresentar exemplos que ilustram como o solilóquio habilita o acesso à intimidade, promovendo o efeito de autenticidade ${ }^{15}$.

Em relação à (i) confissão/revelação emocional, ela corresponde ao que se considera a típica função dramática do solilóquio de exibir emoções que estão à flor de pele; não se trata de algo profundo e secreto que a pessoa tenta ocultar, mas uma reação quase fisiológica interna que é explicitada, exteriorizada ou amplificada, e cujo significado é desenvolvido como uma forma de amplificação essencial em $M C$, qual seja, um interpretante emocional ${ }^{16}$ : euforia, choque, tristeza, acompanhada de um comentário verbal redundante. Um exemplo para ilustrar esse tipo de solilóquio pode ser obtido no episódio analisado de $M C-B R$, quando a apresentadora Ana Paula Padrão relembra aos participantes que para vencerem a competição haveria algo que eles deveriam necessariamente fazer bem: cozinhar. Contudo, a apresentadora informa que naquele episódio em particular, nenhum dos participantes iria preparar alimentos, e solicita que todos retirem seus aventais (não informando o motivo da instrução) ${ }^{17}$. A participante Cecilia protagoniza um solilóquio após a solicitação da apresentadora do programa, durante o qual seu corpo apresenta nervosismo e desconforto pelo

veiculadas, o que sugere um monólogo - de fato, neste caso, na sua construção, trata-se de um diálogo entre o participante e o profissional de produção, cuja real natureza é oculta (como acontece às vezes no gênero documentário). Essa situação é abordada adiante, na variante (iv) a forma híbrida ou impura do solilóquio.

15 Deve ser destacado, contudo, que é sabido o uso de recursos de edição do programa - conforme mencionado anteriormente, os depoimentos são gravados em vários momentos (inclusive após a confecção dos pratos, e mesmo após a eliminação do participante em um programa específico) e são, através de recursos de videoteipe, inseridos no programa em momentos determinados, construindo uma narrativa desejada pela equipe de produção.

16 Peirce define o interpretante emocional como: "o primeiro efeito significativo próprio de um signo é um sentimento [feeling] produzido por ele. Há quase sempre um sentimento que chegamos a interpretar como evidência de que compreendemos o efeito próprio do signo" (CP 5.475).

17 Espécie de crachá funcional, o avental é o objeto/a materialidade que habilita o candidato a participar do programa (Marquioni; Oliveira, 2015, p. 89). 
fato de ter sido solicitada a execução de uma tarefa que constitui um signo ominoso em MC: a ação de retirar o avental é executada em todo episódio pelo participante eliminado do programa (a figura 1 ilustra, no caso do episódio da temporada brasileira em análise, o momento quando um participante eliminado deposita sobre a bancada de trabalho o seu avental que acabou de retirar). Cecília declara que "É difícil a sensação de tirar o avental aqui no $M C$, porque isso significa geralmente eliminação! Assim... não me sinto confortável em tirar o avental...." Apesar de este poder ser considerado um comentário corriqueiro, óbvio, há o fato de exibir uma fraqueza, a emoção do temor pela possibilidade de sair do programa (o que habilita classifica-lo como uma revelação emocional). Outro exemplo pode ser obtido em MC-US: a participante Stacey menciona em solilóquio em relação ao participante Ryan que ela estaria "desapontada [com o fato de] que Ryan esteja entre [tenha sido eleito como um d] os três melhores [pratos do dia]. Ele é como a nuvem negra do grupo"18 (as formas de expressão de seu rosto contribuem com o tom de desaprovação - um frame obtido no momento desse depoimento pode ser observado na figura 2).

Figuras 01 e 02 - Participante eliminado deposita seu avental na bancada de trabalho; fisionomia da participante Stacey reforça o tom de desaprovação de seu solilóquio.

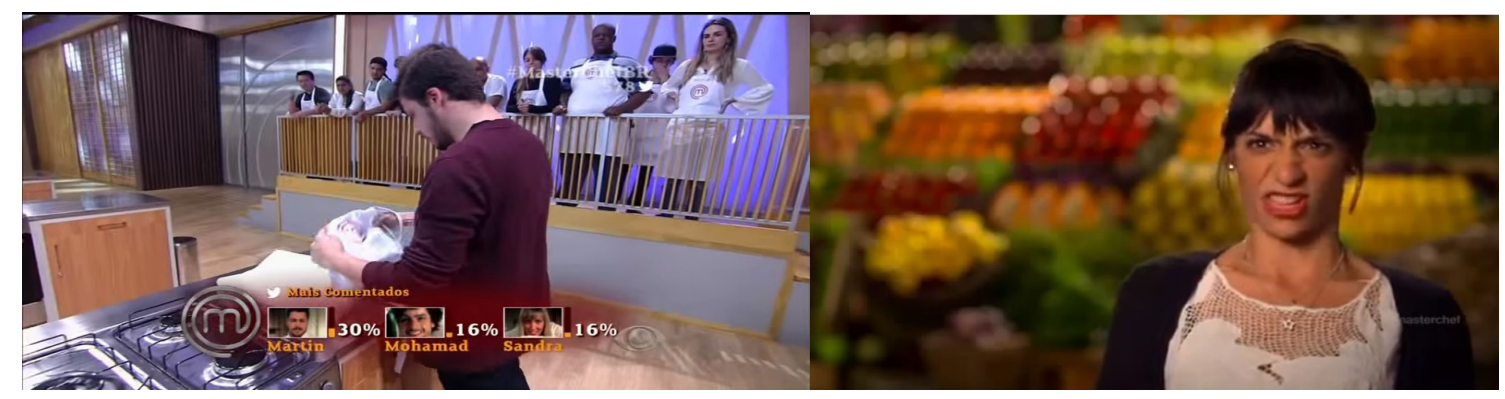

Fonte: MC-BR; MC-US.

De fato, a arrogância ou qualquer outro defeito moral muito visível em um dos competidores tipicamente estimula a produção desta classe de solilóquio nos demais participantes do programa. Neste sentido, vale citar o participante da segunda temporada da edição argentina de $M C$ que pode ser considerado um

18 Aqui vale uma breve observação adicional: é possível observar a ocorrência da noção de "personificação" (Talcott, 1915, p. 118) em MC; o monólogo no programa não apenas cria o efeito de autenticidade, mas também auxilia na criação de personagens em relação aos competidores, em função dos atos referenciados (são típicas as situações em que é possível encontrar o arrogante, o humilde, o engraçado etc.). 
vilão perfeito ${ }^{19}$ : Alejo. Em MC-AR é realizada uma prova rápida de conhecimento, em que os competidores, ao invés de cozinharem um prato, necessitam identificar corretamente a maior quantidade possível dos ingredientes exóticos dispostos sobre uma mesa ao longo de trinta segundos. Alejo vence o mini desafio e, como 'prêmio' pela vitória, é informado que poderia escolher de quais competidores (dentre os que iriam cozinhar com ele durante uma prova de eliminação) ele gostaria que fosse reduzido o tempo disponível para o preparo do prato. Iriam participar de tal prova, além do próprio Alejo, outros três competidores: Jacinto, Alan e Martín. Alejo poderia reduzir em cinco minutos o tempo disponível de cada competidor durante a prova de eliminação, ou optar por remover quinze minutos de um único concorrente. $\mathrm{O}$ vilão da narrativa da segunda temporada argentina opta por remover todos os quinze minutos do concorrente Martín. Quando questionado por Mariano Peluffo (apresentador do programa) sobre o motivo da opção, perante os candidatos, Alejo justifica sua decisão com um elogio: "sinto que ele é muito capaz". O comentário é relevante em função do solilóquio de Alejo que é apresentado em seguida, um dos mais explícitos e fortes no que diz respeito à identidade do competidor como o vilão oficial da temporada. Com um estilo muito próximo de um personagem teatral como lago (de Otelo, O Mouro de Veneza de Shakespeare), ele nega o elogio da notável capacidade do rival que ele mesmo anunciara publicamente há pouco, e realiza um depoimento típico de um reality show (envolvendo jogo, estratégia): Alejo admite que sua decisão fora associada a seu interesse em aproveitar do fato de Martín estar sempre "na corda bamba [em vias de ser eliminado] ${ }^{20 ", ~ m a s ~}$ optou pelo elogio para que seu concorrente "não se ofenda muito". Finalmente, um último exemplo claro da revelação emocional (e talvez inclusive um caso limite com a confissão - abordada a seguir), pode ser apresentado em relação à competidora Bianca $(M C-B R)$. O descontentamento experimentado pela participante não deveria, a priori, ser exprimido publicamente: em um momento do episódio, a apresentadora Ana Paula Padrão faz um suspense em relação ao último voto que iria resolver uma situação de triplo empate entre competidores que haviam sido eliminados, mas dentre os quais um deles retornaria ao

19 O participante Alejo é considerado aqui como um vilão perfeito pelo fato de ele atuar ao longo de toda a segunda temporada (da qual inclusive sagrou-se vencedor) como um total e cínico individualista. Diferente do comportamento típico dos participantes de MC (que estabelecem vínculos e criam grupos de afinidades no programa), Alejo só tem inimigos, rivais, pessoas a quem vencer.

20 Pouco antes, no mesmo episódio, em outro solilóquio, Alejo fizera um trocadilho com a mesma expressão: "Se eu quero ficar [permanecer na competição] tenho que jogar, e eu disse bom, dou isso para Martín [a remoção do tempo], que está na corda bamba, eu tiro tempo dele, talvez sua corda se corte." 
programa (a própria Bianca não estava envolvida no triplo empate - logo, a chance dela própria retornar ao programa era nula). No solilóquio, Bianca abre mão do decoro, das regras de etiqueta que lhe impediriam dizer do modo aberto utilizado o que ela está sentindo em uma situação pública (pois, sugere raiva e frustração): "Para mim é jogar sujo! A tensão que a gente passa aqui, a gente boa que já saiu, para chegar agora e ficar nesse joguinho [= o mistério em revelar o competidor que iria retornar à disputa]! Acho que não!". Neste caso, o solilóquio citado revela a ex-participante Bianca como uma pessoa que tem dificuldade em aceitar a derrota, alguém que não tem flexibilidade em absoluto. Este é um índice forte de autenticidade revelado pela fala mas, sobretudo, pela emoção, e pode ser entendido como um aspecto negativo da identidade da participante. O fato de não ter recebido nenhum voto positivo motiva-a a ficar raivosa com o procedimento, com o mecanismo de $M C$, sem refletir em sua incapacidade para produzir algo bom ou melhor que os outros participantes que foram julgados nesse episódio. Os sentimentos negativos expressados no solilóquio são considerados como verdadeiros, autênticos, justamente porque exibem uma fraqueza da pessoa, em contraste com as falas nos diálogos, nas quais, de modo geral e convencional, há uma evidente procura de parecer alguém do bem. A figura 3 apresenta um momento do semblante da competidora durante o solilóquio.

No que diz respeito à (ii) confissão vergonhosa ou íntima, ela implica se despir em público do decoro, da inibição, para revelar aquilo de mais profundo, de sentimentos poderosos mas não aceitáveis no âmbito público. Trata-se de um momento que na tradição ocidental reserva-se para os íntimos ou para a relação com a religião, o espiritual, e envolve atitudes suspeitas, não exibidas normalmente para evitar ser julgado negativamente como, por exemplo, pela inveja, cobiça etc. É possível mencionar o exemplo da competidora Helene (em MC-US), que menciona a vergonha, a humilhação que sentia em relação ao prato que elaborou e que a colocara como a potencial eliminada do episódio: "Eu sei que meu prato não atingiu o patamar. Eu me sinto envergonhada, humilhada". No caso de $M C-A R$, ainda em relação ao mini desafio de identificação de ingredientes exóticos, há dois solilóquios que caracterizam confissões íntimas: em um momento, Alejo utiliza uma hipérbole brutal ao dizer que, para ganhar a competição, pode ter atitudes extremas: "quero cortar cabeças". A figura 4 é um frame obtido durante este monólogo de Alejo, e apresenta a fisionomia do vilão no exato momento em que afirma ter vontade de decapitar os demais competidores para vencer a segunda edição argentina da franquia MC. Martín, por outro lado (o competidor que tivera o tempo para o preparo do prato 
reduzido em quinze minutos por Alejo) exprime também desejos que tendem a não ser mencionados publicamente:

me deu uma raiva terrível [quando foram removidos os quinze minutos] e quero saltar para agarrá-lo pelo pescoço e matá-lo [a Alejo] nesse instante, porque acredito que é uma atitude muito desleal [remover todos os quinze minutos de um único competidor].

- Figuras 03 e 04 - Participante em solilóquio associado a desaprovação ética; semblante de Alejo ao informar que poderia cortar cabeças para vencer.

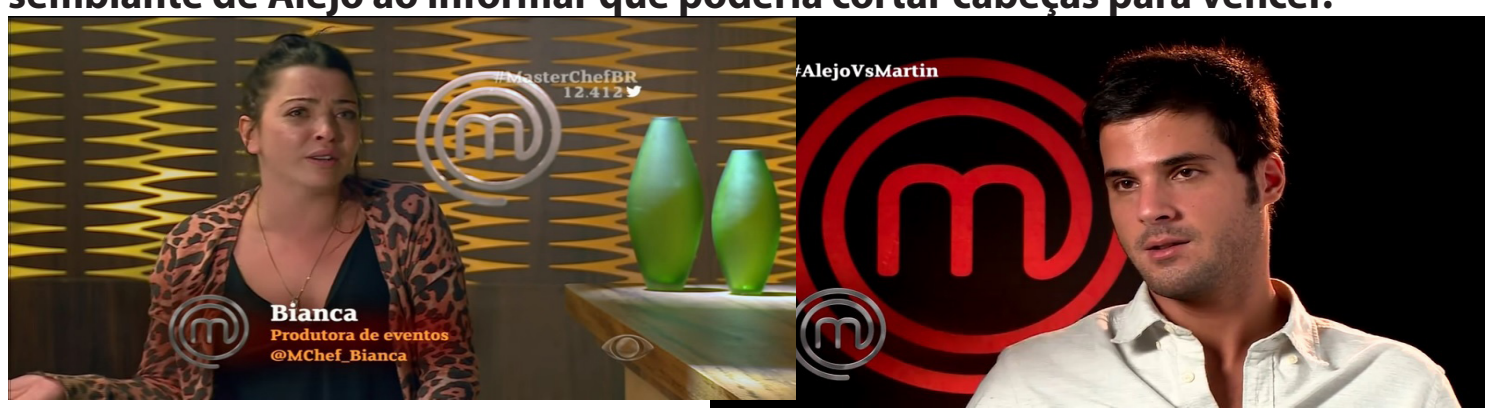

Fonte: $M C-B R ; M C-A R$.

O testemunho fundamental que funciona como uma garantia da autenticidade do expressado no solilóquio é exibido pelo corpo do participante. O material indicial é fundamental porque funciona como um sintoma de autenticidade, além dos signos verbais usados; neste sentido, no caso de Alejo, o semblante apresentado na figura 04 apresenta ainda uma característica curiosa, abordada adiante. O seguinte exemplo é relevante porque faz parte da construção de outro vilão (neste caso, de MC-US): o criticado e maquiavélico Ryan. Tudo começa quando os chefs/jurados explicam a Ryan a vantagem que alcançou a partir da vitória na prova realizada: ele pode escolher a proteína que os outros competidores devem usar na preparação de seus pratos. Ryan escolhe como ingrediente o caranguejo, em duas versões: tanto o animal ainda vivo como enlatado; Ryan explica que sua escolha vai possibilitar eliminar da competição vários de seus colegas. A reflexão é dita em voz alta e não é dirigida a ninguém em particular, assim sua fala poderia ser perfeitamente um pensamento interior, de algo que normalmente produz constrangimento quando é expresso publicamente - no caso, o desejo explícito de eliminar os outros participantes do jogo - e que, portanto, só deveria ser dito em segredo. Em seguida, Ryan é informado que pode decidir o tipo de caranguejo (fresco, 
ainda vivo, ou enlatado com o qual cada competidor vai cozinhar. Depois de tomar conhecimento dessa vantagem, a produção de $M C$ decide que a euforia de Ryan merece um solilóquio. Em seu depoimento, ele vai se gabar de que é maravilhoso estar nesse momento no lugar do condutor do programa, porque ele tem supostamente o poder de decisão sobre "a vida e a morte", isto é, a permanência ou a eliminação dos outros participantes: "E eu vou jogar este jogo tão estrategicamente quanto eu possa", complementa. Desse modo, Ryan mistura (sem transição ou alguma diferença notória) o diálogo totalmente roteirizado, padronizado com os três chefs/jurados - que lhe pedem opinião sem deixar de elogiar sua capacidade como ótimo jogador -, e os breves solilóquios nos quais ele comenta a brilhante estratégia que ele traçou para vencer seus concorrentes. Tudo acontece no programa como se Ryan fosse quase um jornalista de si próprio, encarregado de fazer o comentário final sobre sua jogada, tal como isso poderia ter sido feito por um profissional da mídia em um programa sobre MC: "A tática de guerra psicológica está agora plenamente ativada!". De fato, Ryan justifica com suas falas a queixa e a denuncia citada anteriormente de outra participante no mesmo episódio ("Ele é como a nuvem negra do grupo"). Essa impressão negativa é reiterada - caracterizando um aspecto didático, um letramento realizado continuamente pelo reality - por outra participante, Monti, que diz em um breve solilóquio que Ryan deve estar gostando muito de sua posição no episódio em questão, "porque ele é um perverso!". Numa espécie de momento de comédia stand up, como se fosse um esquete humorístico perante todos os competidores, um chef/jurado pergunta a Ryan quem definiu o tipo de caranguejo (vivo ou envasado em lata) que cada participante iria cozinhar. Com um sorriso no rosto, o cruel competidor aponta para seu peito e afirma que ele foi o responsável por definir. A câmera exibe os rostos chocados dos demais participantes. Volta o foco da câmera para a jovem Monti, que diz: "Eu sabia na hora que ele ia me dar o caranguejo em lata. Eu odeio seu rosto!". Quando, pouco tempo depois, Monti confirma a escolha do ingrediente não fresco (é possível observar uma lata de caranguejo lhe aguardando no armazém), a competidora fala um palavrão e faz um trocadilho com o nome do ingrediente em inglês: "Tomara que Ryan pegue piolhos do púbis! [I hope Ryan getscrabs!]" - a fisionomia de Monti quando conclui tal declaração é apresentada na figura 05. Com evidente crueldade, Ryan atribuíra ainda um caranguejo vivo para a competidora cega Christine; em relação a essa decisão, novamente Monti, como se fizesse parte de um coro grego de só uma pessoa, comenta a atribuição do caranguejo vivo a Christine: "Que classe de [palavrão eliminado da trilha sonora] dá um caranguejo vivo a uma moça cega?" (fisionomia disponível na figura 06). 
Figuras 05 e 06 - Monti questiona e condena a conduta de seu oponente Ryan.

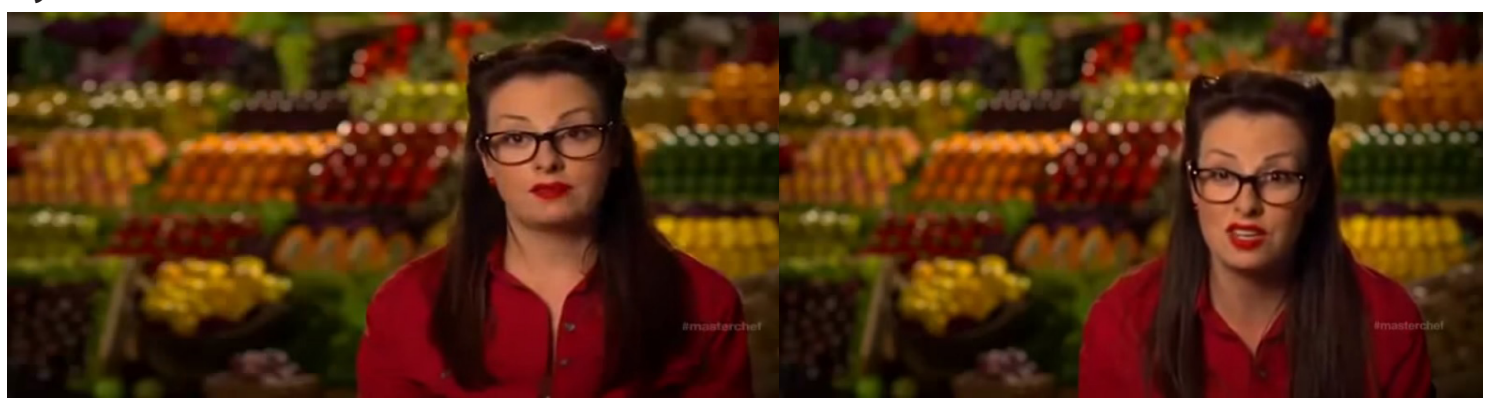

Fonte: MC-US.

Em relação à (iii) glosa ou comentário completamente corriqueiro, ela envolve falas que poderiam ser realizadas em conversas com qualquer pessoa, mas que ganham um sentido especial quando são feitas perante a câmera por alguém que fala sozinho - ocorre que "um monólogo equivale a importância [ - conforme mencionado anteriormente]: [a] o participante dada a voz sozinho para câmera é atribuído um poder"(Aslama; Pantti, 2006, p. 178). Como exemplos desse formato de solilóquio podem ser citados os comentários realizados pelos participantes já eliminados que são convidados a uma'repescagem' (na primeira parte do episódio analisado de $M C-B R$, os competidores eliminados preparam um prato, e aquele que cozinhar o melhor prato será reintegrado à competição). Quando são informados que deverão preparar uma moqueca, os monólogos apresentados possuem um caráter definitivamente corriqueiro. A competidora Marli, por exemplo, afirma: "costumo me sair bem fazendo moqueca; não pensei em preocupação nenhuma [que teria com a elaboração do prato]". No caso de MC-US é possível mencionar o comentário de Ryan, que torce por si próprio no momento em que vai ser anunciado o vencedor de uma prova realizada (também, claro, um sintoma de sua elevada autoestima, de sua vaidade); seu solilóquio faz entender que o candidato tem certeza de ter vencido o desafio, e só aguarda que seu nome seja dito pelo chef/jurado: “Diga, Gordon! Eu quero ouvir meu nome!" - a fisionomia de empolgação do vilão Ryan, com ar de riso enquanto declara no solilóquio que torcia para si pode ser observada na figura 07. Em MC-AR, há um depoimento interessante do participante Alejo, que afirma: "sou muito competitivo, e quando se trata de ganhar algo tiro todo meu cérebro para fora". Neste caso, trata-se de um comentário do vilão portenho que pode ser considerado como banal, e poderia ser realizado em uma conversa qualquer. A figura 08 apresenta o semblante de Alejo ao realizar tal comentário: é interessante notar que sua fisionomia, apresentada na figura 
08, possui poucas variações quando comparada com o semblante apresentado na figura 04 (relativa ao solilóquio no qual ele utiliza a hipérbole que poderia cortar cabeças para vencer). Essa uniformidade e constância indicial auxiliam a compor o personagem do vilão da temporada, elas correspondem ao já citado conceito teatral de "personificação" (Talcott, 1915).

ש Figuras 07 e 08 - Ryan torce para si próprio; Alejo se diz competitivo.

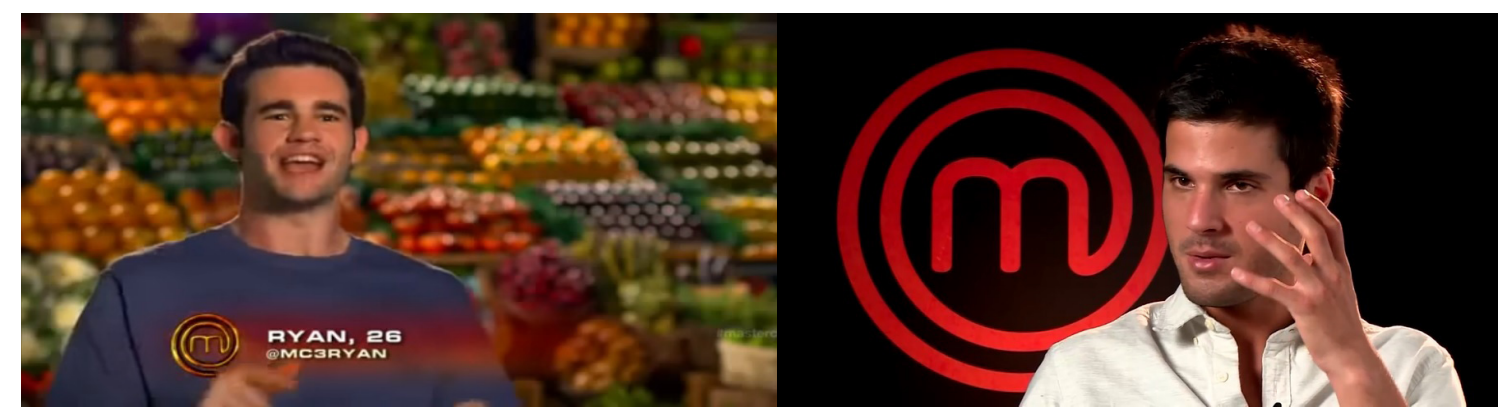

Fonte: MC-US; MC-AR.

Como quarta classe pode ser mencionada a (iv) forma híbrida ou impura do solilóquio. Esse tipo de monólogo acontece quando, no meio da tarefa do ato de cozinhar), o participante comenta algo sobre o momento. Assemelhase à performance do apresentador de um programa clássico de cozinha. Está no limite entre esse discurso reflexivo-didático e a confissão genuína, que se foca mais na auto revelação, nas emoções fortes, que seriam índices corporais da autenticidade dessa realidade íntima e última exibida em $M C$, o si mesmo verdadeiro. Falta também o espaço íntimo, afastado, separado da ação coletiva para que a confissão seja completa ou pura. Trata-se de casos da ação de quem pode ser considerado o cronista invisível, como acontece em muitos documentários, quando o espectador só observa e assiste ao depoimentoresposta do entrevistado, sem ouvir nem enxergar a pessoa que obviamente fez a pergunta. A rigor, conforme mencionado, os depoimentos prestados enquanto os participantes cozinham são tipicamente associados a respostas para questionamentos realizados por profissionais da produção do programa, que fazem perguntas aos competidores. No caso de $M C$ - $B R$, o comentário de Jamyly ilustra o tipo de solilóquio: "Hoje vai decidir [= vai vencer] um bom tempero. Quem tem um bom tempero fica, quem não tem... Paciência [, será eliminado da competição]" - a figura 09 é um frame obtido durante esse depoimento.

Finalmente, em relação à (v) propaganda quase explícita do show: uma apologia pro realidade sua, trata-se de uma forma ideológica quase explícita. Com um tom emocional, mas formal e solene, o participante usa o monólogo nesses casos para fazer uma declaração, próxima de um manifesto pessoal- 
institucional sobre os admiráveis princípios morais de $M C$ enquanto programa de televisão. São tipicamente avaliações da contribuição do formato para a qualidade das pessoas em geral e para o participante em particular, da profissão culinária etc. Um exemplo pode ser citado em relação à espécie de epílogo que Cecília faz para o programa $(M C-B R)$, ao enunciar os valores morais do formato. O tom de sua voz é solene, declamatório, como alguém que está falando não apenas para o público que assiste, não só para o presente, mas para a posteridade; ela está se dirigindo para a História com sua declaração: "Os melhores têm que ficar para que o melhor potencial seja mostrado. Quando você sai do $M C$, você vai estar no mundo real, com todos os chefs premiados, estrelados e você vai competir com gente real e gente muito boa!". Há uma equivalência explícita entre esse formato televisual, uma mistura de reality e talent, e o mercado ou inclusive a vida mesma, onde alguém se torna um chef, e eventualmente pode ter muito sucesso (na contemporaneidade, inclusive fama). A visão apresentada no solilóquio de Cecília é o mundo como uma constante competição para encontrar o melhor, o que, portanto, não seria muito diferente do que acontece em $M C$.

Outro exemplo da propaganda da ideologia de $M C$ pode ser obtido no discurso de adeus, muito elegante e resignado que acontece quando a competidora Helene (MC-US) é eliminada da competição. Ela menciona sua ambição: “Eu vou atrás de meu sonho, com ainda mais entusiasmo que antes! [em função do aprendizado que tivera]" - a competidora destaca que vai tentar continuar a estabelecer sua carreira de chef em outro lugar; a fisionomia no momento deste solilóquio é oferecida na figura 10.

\section{Figuras 09 e 10 - Solilóquio de Jamyly enquanto cozinha; solilóquio de despedida de Helene.}

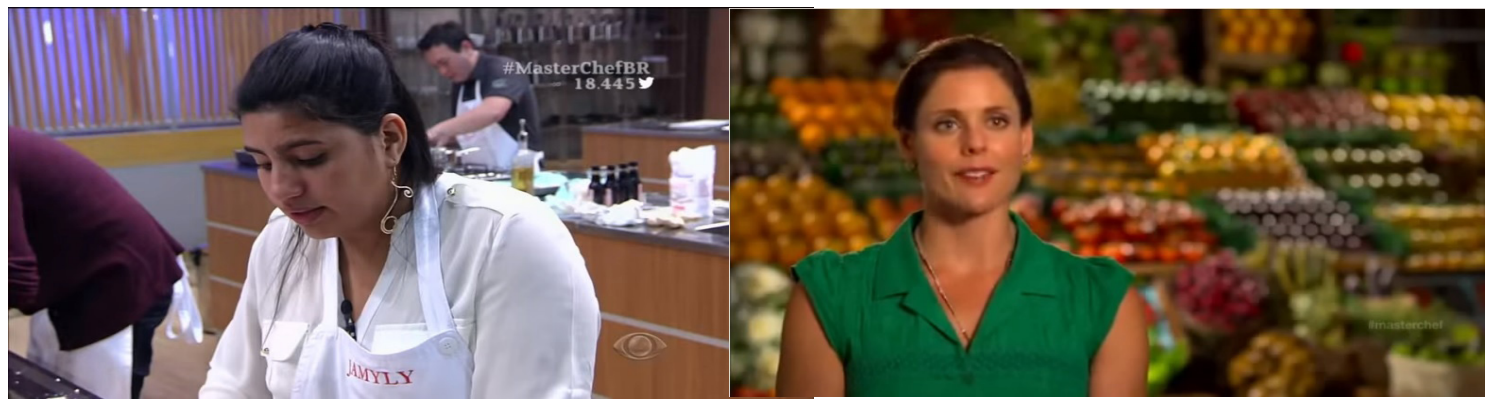

Fonte: MC-BR; MC-US.

Porém, Helene também confessa que sente essa derrota para seu orgulho. Assim temos a mistura de uma propaganda sobre a moral supostamente elevada de $M C$, associada a um depoimento próximo da típica confissão, mas dita como parte de um manifesto ou uma declaração solene. Inclusive num 
paroxismo ético, Helene fala de sua missão, da filosofia sobre a comida que ela tinha intenção de compartilhar com todos os Estados Unidos da América. Sua fala encaixa com um discurso formal que enuncia a vontade de fazer um mundo melhor, no contexto televisual do reality/talent.

\section{Considerações finais}

Nosso intuito neste artigo foi demonstrar a importância do uso do solilóquio na economia narrativa de um programa de TV, o formato híbrido de reality e talent show $M C$. Do ponto de vista macrossocial, a estratégia pertence à "cultura da autenticidade" Taylor (2007), que começou com o Romantismo no século 18, e na qual o essencial é o desenvolvimento da "expressividade" do indivíduo. Na televisão atual, esse ato de fala pouco natural funcionaria como o caminho real ao si mesmo genuíno dos participantes, um troféu tão importante no programa quanto a contemplação do talento culinário dos chefs amadores. Estabelece-se, assim, um espetáculo insólito: a popularidade de $M C$ deve-se tanto à revelação psicológica quanto culinária. Sem minimizar o componente gastronômico, que faz parte do nome e do funcionamento de cada etapa do programa, entende-se que haveria um tempero central e espetacular para o público que, conforme nossa análise, poderia explicar a popularidade mundial da franquia MC: a atração interminável do ordálio da identidade. Nos exemplos extraídos de três edições locais de $M C$ analisados, é possível observar a duríssima e extensa prova para o si mesmo, e cujo resultado não teria a ver apenas com o talento culinário de cada participante, mas também com os sentimentos e emoções que são revelados no ato de fala solitário. Quem é esse participante verdadeiramente, além da exibição da técnica com que prepara os pratos exigidos pelos chefs/jurados? Como ele reage - a produção intensa e constante de signos indiciais - quando recebe uma punição ou um obstáculo proposto por um colega, como resiste ao impulso de exibir sua raiva, sua decepção, sua tristeza? Todos esses sintomas emergem no espetáculo do solilóquio. Entende-se que esse poderia ser o prato mais cobiçado do programa; os demais, preparados em cada bancada de trabalho constituiriam apenas a entrada da refeição televisual mais esperada, um prato que não é comestível mas sim visível e audível: a experiência da máxima intimidade imaginária com outrem.

Como surpresas decorrentes do estudo do leque de casos do solilóquio, descritos como'variantes de acesso à intimidade' dos aprendizes de chef, pode-se destacar que, de fato, duas delas não procuram exibir o si mesmo verdadeiro, não revelam a identidade, que no diálogo pode ser ocultada com estratégias verbais de sociabilidade para ser legitimado pelos outros. Na televisão contemporânea, o solilóquio tornou-se uma língua franca ou meio de comunicação naturalizado 
para exprimir questões completamente alheias à "cultura confessional ou terapêutica" (Aslama; Pantti, 2006). Além da clássica exibição dos pensamentos, das emoções íntimas que somente são compartilhadas consigo mesmo, ou com as pessoas mais próximas, há exemplos de propaganda explícita dos supostos princípios éticos do programa de televisão no qual estas pessoas participam, ou do qual eles estão indo embora. Na era do reality/talent show, o solilóquio dramatúrgico não seria já usado apenas para a confissão, o momento quando surge a expressão convencionalmente secreta e solitária do que se quer ocultar dos outros - como acontecia no teatro isabelino - mas serve também para a exposição de questões políticas ou corriqueiras. Isso permite pensar em uma estética ampliada da intimidade que abrange instâncias televisivas muito diversas, algumas delas de natureza pública, como a avaliação ética do programa, ou comentários banais, aqueles que são feitos em forma de diálogo, na vida cotidiana. Haveria, no primeiro caso, uma espécie de ventriloquismo funcional: nessa hora, o participante desempenha o clássico papel do apresentador de $M C$, ao elogiar as virtudes sociais e culturais, e sobretudo didáticas do programa. A ironia que vale a pena mencionar é que não se trata de uma pedagogia culinária - isso tem uma importância mínima, quase nula no programa, porque as pessoas não assistem para aprender a cozinhar - mas de uma pedagogia da vida virtuosa. Assim, sem negar a importância da competência culinária demostrada pelos participantes (o aspecto talent de $M C$ ), conclui-se que o outro aspecto da narrativa (o reality) depende em grande medida dos frequentes solilóquios. Estes atos de fala nada normal são os interpretantes emocionais normais ou corriqueiros do programa; estes signos explicam como a expectativa normal do espectador de $M C$ é poder experimentar a máxima proximidade das emoções dos participantes, inclusive quando o solilóquio não abre as janelas da alma, mas encarrega-se apenas de elogiar as supostas bondades do programa para a sociedade. Uma conclusão possível seria que a estética da intimidade ampliada deste gênero televisual determina que o solilóquio em $M C$ seja utilizado para fins bem diversos do objetivo clássico, confessional, de exibir as emoções mais autênticas da pessoa, seu si mesmo verdadeiro. Com a passagem do tempo, esta ampliação do âmbito íntimo poderia conduzir à banalização do solilóquio como veículo privilegiado da identidade humana no âmbito da televisão contemporânea.

\section{REFERÊNCIAS}

MARQUIONI, C. Eduardo; OLIVEIRA, Caroline Cavalcanti. Para além da competição: consumindo afetos como cultura material no programa MasterChef (análises 
e reflexões iniciais). In: Conexão - Comunicação e Cultura, v. 14, n. 28. p. 71-95. Universidade de Caxias do Sul. Caxias do Sul, 2015.

ANDACHT, Fernando. El reality show: una perspectiva analítica de la televisión. Buenos Aires: Grupo Editorial Norma, 2003.

ASLAMA, Minna; PANTTI, Mervi. Talking alone: Reality TV, emotions and authenticity. European Journal of Cultural Studies, London, v. 9, n. 2, p. 167-184, 2006.

PADRÃO, Ana Paula. Entrevista presencial concedida pela apresentadora da primeira, segunda e terceira temporadas de MasterChef Brasil para Caroline Cavalcanti de Oliveira e Carlos Eduardo Marquioni. São Paulo, 20 set. 2014.

PEIRCE, Charles Sanders. The Collected Papers of C. S. Peirce Vols. I-VIII. HARTSHORNE, Charles; WEISS, Paul; BURKS, Arthur (orgs.). Harvard Mass.: Harvard University Press, 1958.

ROZNOWSKI, Rob. Inner Monologue in Acting. London: Palgrave Macmillan, 2013.

TALCOTT, R. A. The place for personation. Quarterly Journal of Speech, v. 2, n. 2, p. 116-122, 1915.

\section{http://dx.doi.org/10.1080/00335631609360528}

TAYLOR, Charles. A secular age. Cambridge: The Belknap Press of Harvard University Press, 2007.

WALLACE, Clare. Introduction. In: (org.). Monologues: theatre, performance, subjectivity. Prague: Litteraria Pragensia, p. 1-16, 2006.

WILCE, James M.; FENIGSEN, Janina. Introduction: De-essentializing authenticity: A semiotic approach. Semiótica n. 203, p. 137-152, 2015.

WILLIAMS, Raymond. Cultura. São Paulo: Editora Paz e Terra, 2008.

A produção social da escrita. São Paulo: Editora Unesp, 2013.

Submetido em: $7 / 7 / 2016$

Aceito em: 15/8/2016

Endereço dos autores:

Carlos Eduardo Marquioni <cemarquioni@uol.com.br>

Universidade Tuiuti do Paraná - Campus Prof. Sydnei Lima Santos (Barigui)

Rua Sydnei Antonio Rangel Santos, 245 - Santo Inácio

82010-330 - Curitiba (PR) - Brasil

Fernando Andacht < fandacht@gmail.com $>$

Departamento de Teoria e Metodologia

Fac. de Información \& Comunicación

Universidad de la República

Av.18 de Julio 1968

Montevideo - Uruguay 